\title{
The Influence of Students' Experience on Alumni Giving in Malaysian Public Educational Institution
}

\author{
U. Naeimah Saraeh ${ }^{1}$, , Nor Irwani Abdul Rahman', Norshahrizan Noordin', Sayang Nurshahrizleen Ramlan ${ }^{1}$, Razli Ahmad ${ }^{2}$ \\ and Mohd Fo' ad Sakdan ${ }^{2}$
}

${ }^{1}$ School of Business Innovation and Technopreneurship, Universiti Malaysia Perlis (UniMAP), Malaysia

${ }^{2}$ School of Human Development and Technocommunication, Universiti Malaysia Perlis (UniMAP), Malaysia.

\begin{abstract}
The purpose of this study is to examine the influence of students' experience on alumni giving in one of Malaysian Public Higher Educational Institution (PHEI). Utilizing the questionnaire method, data are obtained from 347 respondents among final year students in this institution. Results presented indicate students in this institution have low level of students' experience and alumni giving with the mean score are reported at 1.25 each. Results presented also indicate that students' experience is significantly related to alumni giving $(\beta=.54, \mathrm{p}<.01)$. This study contributed some new knowledge to the existing literature in the domain of alumni giving behaviour. Several recommendations can be suggested to Malaysian PHEIs to improve their level of students' experience, thus the level of alumni giving can be increased. Several recommendations are proposed to be enhanced so as to increase the satisfaction on students' experience during their undergraduates' life based on this study findings.
\end{abstract}

\section{Introduction}

Alumni giving is a crucial issue. Most of the institutions wonder how they can increase the level of alumni giving in both financial and non-financial aspects. However, it may become more important to understand the factors which may create the influence on alumni giving, particularly to support their undergraduate alma mater. Even there are many factors after graduation which contributes to alumni giving (eg. salary, alumni loyalty, alumni involvement); but the effect on how students' experience during their universities' life toward their future alumni giving behaviour is one of the factors which is salient to be examined. This is supported by [1] who presented that willingness to contribute for alma matter is affected by the undergraduates' experiences (students' experiences). Hence, it shows that factors on how student views of the institution during their life in campus are deemed important to be examined.

This answer why it is become crucial for the institution to identify in what aspects students' experience may create an influence on their future alumni giving while the students are still in the campus. Thus, aiming at the final year students to reveal the experience towards their future alumni giving could potentially contribute some information to the institutions. Consecutively, the institutions can develop their capacity to strengthen their future strategies.

Not only that, the Ministry of Higher Education Malaysia (MoHE) also has taken several initiatives by making alumni as one of the external parties to realize the goals of internationalization. Therefore, to realize the objective for universities' internationalization, it is expected that the factor of alumni giving can contribute to increase the institution's performance.

Moreover, all HEI including the public institution need such private (external) support such as from the alumnus as a revenue stream which can attribute to the continual decrease in the level of state appropriations [2]. In an effort to compensate for the decrease in state appropriations and increase in educational costs, institutions are placing more emphasis upon alternative on the private support (eg. alumni) to sustain a competitive advantage amongst the universities. As [2] highlighted that while there are several alternatives nontuition revenue sources that could be explored (eg. alumni talk series, research grants); alumni giving continues to be a promising possibility. Moreover, in this current economic situation, alumni giving are something which all institutions cannot ignore.

Given that alumni giving is formed while they are still students [1]; thus, forming an understanding of the experiences which students have with their alma maters would provide insights into the future alumni giving behaviours. (eg. alumni financial and non-financial contribution). In other word, students' experience in the university is the best platform to reveal the intention of their future alumni giving.

In addition, lack of evidence of alumni survey is found in the local studies. According to [3] the three conceptual approaches of alumni survey are consisted of outcomes; students' engagement and competencies; and alumni giving. Outcomes are the assumption of the institutional quality and effectiveness which can be appraised on what alumni have accomplished. Meanwhile, students' engagement and competencies are

\footnotetext{
"Corresponding author: ummi@unimap.edu.my
} 
the assumption of the institutional quality which can be appraised to what the students did at institution, learned and applied; and alumni giving are the assumption of a function of positive experiences with the institution and ability to contribute. Hence, it becomes a priority for the researchers to explore and examine one of the alumni survey especially on the issue of alumni giving in the context of Malaysia.

Moreover, in the local context, limited evidence of the local research is found on the relationship between students' experience and alumni giving. Thus, few developments can dramatically impact on the students' experience if this factor is found to influence the alumni giving level in the Malaysian HEI.

\section{Literature Review}

\subsection{Students' Experience}

To date, students' experience has a major impact on feelings and opinions towards the institution when they become the alumni $[4,5]$. Previous authors claimed that students' experience became a popular variable among the higher educational managers but is still theoretically under-developed [6], thus the influence of students' experience should be examined particularly on the contribution of alumni giving.

In addition, [7] stated that alumni who enjoyed their students' experience gave positive feedback to people in their networks, acted as role models for the current students, shared their skills and experiences, and advised the program of the alma mater. Fostering a lifelong connection with current students, and later the alumni, is a potential source of support for institutions [8]. Thus, it shows that alumni are a significant part of any university community.

Other authors stated that undergraduate students who have a positive and satisfying experience while enrolled tend to develop lifelong relationships as alumni with the institution. For example, [9] claimed that positive experience includes enjoying classes, developing friendships and obtaining a useful degree. Hence, it can be assumed that being content with the undergraduate experience could mean obtaining a job upon graduation or getting connected to worthwhile efforts that offer challenge for the graduate. Therefore, students' experience is become relevant in shaping the future trend of alumni giving.

In a local context, it has been reported that in year 2016 students have moderate level of satisfaction with the function of one department in this institution. Based on this report, it becomes the opportunities for the researchers to identify the consistency of the students' satisfaction towards their experience in this institution by conducting another research on students' experience in 2017. Therefore, students experience when dealing with several departments in this institution has been investigated.

According to [10], empirical works stated that the strongest giving predictor (eg. alumni giving) is the satisfaction a student had with his or her students' experience. Other authors [11] added that graduates who are satisfied with their college experience are more likely to contribute to the college or university. Similarly, $[4,5]$ confirmed that students' experience while they in campus has a major impact on feelings and opinions toward the institution as alumni.

Thus, in this study the researchers attempt to investigate the satisfaction of students' experience in one of the PHEI in Malaysia. Based on report as presented by the Quality Department in this PHEI, the level of satisfaction among students towards this institution is still moderate. Therefore, studying students' experiences would provide insights into the existing literature in the domain of alumni survey particularly on alumni giving behaviour.

\subsection{The Influence of Students' Experience on Alumni Giving}

The research clearly establishes that among attitudinal variables, satisfaction with the student experience is by far the strongest predictor of alumni giving behaviour (2, 12, 13]. For example, [12] presented that the undergraduate experience became the most significant determinant of alumni giving in several investigation involving with several institutions. This result was supported by other authors [14] who found that donations are highly correlated to satisfaction with the college experience.

However, [15] who looked at the alumni donor participation rates in Pepperdine University, found that undergraduate experiences were not predictors of future alumni giving. The results of [15] study indicated that alumni donor status was better predicted by examining only the involvement of alumni post-graduation than the impressions that an institution left on graduates as their experiences.

According to [16], each study of alumni giving and alumni donor participation has attempted to address the overwhelming question of how to increase alumni donor participation. Early research on alumni giving was conducted largely by economists and sociologists and published rarely in peer-reviewed journals. For decades and until nowadays, most of this research was done as part of dissertation work and as a result, it remains difficult to access. Dissertations have been frequently cited in alumni giving research because of the disparity of articles in peer-reviewed journals on the topic [17].

As stated by [18] research on alumni giving focuses on four areas which consisted of individual donor characteristics, fund raising practices, the external environment, and institutional characteristics. However, in this study alumni giving will be explored in the areas of willingness of the current students to contribute in financial aspect (eg. donation) and the non-financial aspect (eg. alumni talk series such as experience sharing session with the current students).

As cited by [19] in [16], alumni giving in America began at Harvard College with a donation of land in 
1648 by four Harvard alumni. The gift was followed by gifts from other alumni for the remainder of the seventeenth century, and contributed to the establishment and steadfastness of Harvard and other higher education institutions in America Meanwhile, the Yale System, an organized alumnus giving initiative for all alumni of Yale University, sought to increase smaller donations from many instead of relying on only large donations from the few. Literature on alumni development suggests colleges and universities that attain significant alumni giving rates tend to have welldeveloped and implemented strategies, with many focusing on developing current students into giving alumni. HEIs use a variety of traditional and creative methods to cultivate alumni and secure their support [20].

To date, alumni giving is can be assumed as a function of positive experiences with the institution and ability to contribute [3]. It is about the ability and inclination of alumni to support their alma mater through philanthropy, service, and advocacy. It can be measured by the perceptions of the quality (satisfaction) of college experience. Although [21] claimed that alumni giving rates do not adequately measure graduates' satisfaction with educational experience, however research clearly demonstrates that satisfaction with the college experience plays a significant role in alumni giving.

Therefore, this study will look at alumni giving behaviour and determine if students' experience can be identified for explaining the alumni contribution (financial, non-financial) from the Malaysian context. More specifically, the purpose of this research is to explore the level of alumnus future alumni giving in this population. Hence, this study will look at the influence of students' experience on alumni giving behaviour in one of PHEI in Malaysia. It is hoped that this research will stimulate the Malaysian HEIs to re-examine their types of services towards the current students to create and implement creative initiatives to increase alumni giving and, in turn, to strengthen their institutions' strategy.

It is the hypothesis of this research study that a students' satisfaction towards their experience with the institution may generate a greater emotional bond or affinity towards the institution after their graduation and thereby positively influence the alumni giving behaviour to their alma mater. Given the above literature, the specific hypotheses of this research are stated below:

$\mathrm{H}_{1}$ : There is a moderate level of students' experience in this institution.

$\mathrm{H}_{2}$ : There is a moderate level of alumni giving in this institution.

$\mathrm{H}_{3}$ : There is a significant relationship between students' experience and alumni giving in this institution.

\section{Methodology}

The population of this research involved the final year students from all faculties in the institution. This research used questionnaire to obtain data from all participants to the estimation of 500 respondents. The SPSS software (version 22) has been used for the statistical analysis. The instrument used for alumni giving has been adapted from the previous measurement; while the instrument used for students' experience has been developed based on the environment of the institution.

In this research, the final year students need to provide their satisfaction towards the four dimensions of experience consist of teaching and learning activities (3 items), dealing with several departments in the institution (6 items), co-curricular activities (2 items), and their intention as the future alumni ( 2 items).

As for the alumni future attitudes, 4 items of alumni giving have been developed based on the previous authors [2, 3, 8, 18]. Those items are (1) As a future alumni, I believe that financial assistance from alumni is very important in the success of an activity involving alumni with the university; (2) As a future alumni, I believe that financial assistance from the alumni is very important to the development of interactions between alumni and universities; (3) As a future alumni, I would like to make a financial contribution to the university if I am capable; and (4) As a future alumni, I intend to contribute non-financial assistance such as sharing the knowledge, experience and skills that I have with prospective alumni who are still studying at university if I have spare time.

Based on the pilot test, the reliability values of students' experience and alumni giving are reported at .82 and .76 each. In this study, the researchers used the criteria of Cronbach's alpha as established by [22]. Therefore, the reliabilities of variables used in this research are ranged from acceptable to good which mean that all variables can be used for further analysis.

\section{Results and Discussions}

A quantitative method has been utilized in this research. The response rate for this study was at $69.4 \%$ when 347 out of 500 of the distributed questionnaires have been used for this research. Majority of the respondents in this research were female, which contributed of 58.8\% (204 participants). Hence, the remaining of the respondents was male which contributed of $41.2 \%$ (143 participants).

The highest percentage of responses $(20.5 \%)$ was obtained from School of Business Innovation and Technopreneurship; and the lowest percentage of responses (7.6\%) was obtained from School of Material Engineering. Other participants were from School of Electrical Systems Engineering (14.1\%), School of Microelectronics Engineering (12.1\%), School of Computer and Communication Engineering (9.5\%), School of Human Development and TechnoCommunication (9.8\%), School of Bioprocess Engineering (8.9\%), School of Environmental Engineering $(8.9 \%)$ and School of Mechatronics Engineering (8.6\%). 


\subsection{Mean and SD Analyses}

In this research, the interpretation of mean scores has been referred to [23] with the mean scores ranged from low (1.00-2.00), moderately low (2.01-3.00), moderately high (3.01-4.00) to high (4.01-5.00).

As presented in Table 1, the mean value for students' experience was low at 1.25 . Therefore, low acceptance is observed for this variable. Similarly, the mean score for alumni giving was also low at 1.25 . Thus, $H_{1}$ : There is a moderate level of students' experience in this institution; and $H_{2}$ : There is a moderate level of alumni giving in this institution are not supported in this study.

Table 1. Mean and SD Values

\begin{tabular}{|l|l|l|l|}
\hline Variables & $\mathrm{N}$ & Mean & $\mathrm{SD}$ \\
\hline $\begin{array}{l}\text { Students' } \\
\text { Experience }\end{array}$ & 347 & 1.25 & .21 \\
\hline $\begin{array}{l}\text { Alumni } \\
\text { Giving }\end{array}$ & 347 & 1.25 & .22 \\
\hline
\end{tabular}

As for the SD analysis, it is noted that the SD values for students' experience (.21) and for alumni giving (.22) were also low. The low level of SD showed that most respondents were close to the mean for variables in this study.

\subsection{Correlation Analysis}

Pearson correlation coefficient ( $r$ ) is computed to test the correlations and directions between students' experience and alumni giving. As shown in Table 2, a moderate relationship is observed between students' experience and alumni giving $(\mathrm{r}=.53, \mathrm{p}<.01)$. Therefore, the correlation is reported as significantly and positively between each other.

Table 2. Correlation Analysis

\begin{tabular}{|l|l|l|l|}
\hline Variables & N & 1 & 2 \\
\hline Students'Experience & 347 & - & \\
\hline Alumni Giving & 347 & $.39^{* *}$ & - \\
\hline
\end{tabular}

**Correlation is significant at the 0.01 level (2-tailed)

\subsection{Regression Analysis}

Regression analysis is used to investigate the relationship between independent variable and dependent variable as posited in the research hypotheses. By using SPSS, the data is performed for Coefficient for the data.

According to [24], regression is a technique that can be used to investigate the effect of one predictor variable (independent variable) on an outcome variable (dependent variable).

As shown in Table 3, regression analysis result presented that students' experience explained 29\% of variance in alumni loyalty $\left(\mathrm{R}_{2}=.29\right)$. This clarified that $29 \%$ of variance in alumni giving is explained by students' experiences, while the rest of $71 \%$ of variance in alumni giving is explained by the other variables.
Meanwhile, the adjusted $\mathrm{R}_{2}$ value is reported at .30 . This confirmed that students' experiences had strong influences on alumni giving $(\beta=.54, \mathrm{p}=.00)$.

Therefore, $H_{3}$ : There is a significant relationship between students' experience and alumni giving in this institution is supported in this study.

Table 3. Regression Analysis

\begin{tabular}{|c|c|c|c|c|}
\hline Variables & \multicolumn{4}{|c|}{ Students'Experience } \\
\hline & Beta & Sig. & $\mathrm{R}^{2}$ & $\begin{array}{c}\text { Adjusted } \\
\mathrm{R}^{2}\end{array}$ \\
\hline $\begin{array}{c}\text { Alumni } \\
\text { Giving }\end{array}$ & $.54^{* *}$ & .00 & .29 & .28 \\
\hline & & & \\
\hline
\end{tabular}

\section{Conclusion}

Based on the research findings, it can be concluded that the level of students' experience as well as alumni giving among the final year students in this institution were in the low indications with the mean value reported at 1.25 each. Therefore, the first two hypotheses about the appearance of moderate levels of both students' experience and alumni giving behaviour in this institution are not supported this study.

In addition, this study provides some new knowledge on the influence of students' experiences on alumni giving. As presented in Table 3, students' experience is positively associated with alumni giving $(\beta=.54, \mathrm{p}<.01)$. Thus, H3: There is a significant relationship between students' experience and alumni giving in this institution, is supported in this study.

Based on the results, it can be concluded that by increasing the level of students' experiences among the current students in this institution, the future level of alumni giving among them can be enhanced. In the theoretical perspective, these findings had been consistent with the previous findings as reported by several authors $[2,25,26]$.

For example, [2] presented that undergraduates who were challenged by their alma mater, interacted with their respective faculty members, and were provided with the institutional support they needed to accomplish their academic goals, were more likely to giving (contribute) back to their alma mater. This is because the overall levels of satisfaction with undergraduate academic experience were variables that had the highest correlation for alumni giving [25]. Similar findings by [26] presented that satisfaction was greater with the student experience, and giving was also impacted, when students believe they had educational gains.

In order to increase the level of alumni giving in the financial and non-financial aspects, the level of students' experience need to be enforced first. By increasing the level of student satisfaction towards their experience, the future alumni giving could be inculcated. Thus, in the practical perspective, with the advent of contemporary information and technological innovations, the institution should increase the quality level of services as to improve the level of students' experience such as: 1) 
To create a platform for further interaction between students and the academic staff even after teaching and learning session; 2) To create a platform for further interaction between students and the non-academic staffs even after office hours; 3) To enhance the implementation of the buddy system; and 4) To provide a more effective and interactive medium in attending students inquiries and complaints on university's facilities e.g. Library, Bursary, Information Communication and Technology (ICT), Residential Colleges, Students Affair and Alumni Department, Transportation, Cafeterias etc.

Furthermore, there is also a need for universities to show a compelling reason of importance of alumni giving as a cause worthy of donations. It is important to remember that successful alumni giving initiatives may not only take months but many decades. However, there is always opportunity there. Besides, this may continue to drive success between universities with NGOs (eg. Alumni Association Committee) that effectively raise most of their funding from alumni donors.

Today's millennial alumni are much more likely to give when introduced to a specific person who needs their help. What may and usually work with universities today is highlighting a specific student or faculty member and telling potential donors how their gift will make a difference through scholarships, new equipment, new facilities, program funding, etc. This may help when universities are able to show the need, tell how the alumni can alleviate the need and position themselves as a cause worthy of contributions. However, the strategy will not work unless there is a well-established relationship between the university and the alum. This relationship started in their early year in campus. In fact, in previous study, it is found that faculty relationships were hugely important to maintaining these universityalumni connections after graduation.

Regardless of how it is first introduced, the immediate goal for a university is to quickly get graduates into the habit of giving back to the alma mater. The ultimate goal is to sustain that generosity for a lifetime. A true indicator of the love for and loyalty to one's alma mater is the extent to which one is willing to support it financially. It also happens to be a reliable indicator of excellence. As it turns out, graduate giving is a very good barometer of how alumni view their university. Most of world Class University has longstanding traditions of alumni support based on their historic reputation for excellence and a campus life that binds students to the institution and to one another. Alumni financial contributions are one of the best indicators of a graduate's esteem for their university. As is often the case, money follows the heart.

Finally, government efforts to train and educate graduates in alumni giving should be maintained and enhanced. In recommending programs and policies to deal with these key issues, one size does not fit all. Recommendations with respect to alumni giving need to be tailored to the specific context in each PHEIs.

\section{References}

1. Dugan, K., Mullin, C.H. \& Siegfried, J.J. Undergraduate financial aid and subsequent alumni giving behavior. Williams Project on the Economics of Higher Education Discussion Papers, DP-57. (2000)

2. Ropp, C.T. The relationship between student academic engagement and alumni giving at a public, state flagship university, Doctoral dissertation, University of Kansas (2014)

3. Cabrera, A.F., Weerts, D.J. \& Zulick, B.J. Alumni Survey: Three conceptualizations to alumni research, Paper presented before: Métodos de Análisis de la inserción laboral de los universitarios, Universidad de León, España (2003)

4. Sun, X. A multivariate causal model of alumni giving at a Midwest, public university. Dissertation Abstracts International, 66 (12), (2005)

5. Thomas, J.A. The relationship between personal and social growth and involvement in college and subsequent alumni giving. Dissertation Abstracts International, 66 (12), 4323, (2005)

6. Koenig-Lewis, N., Asaad, Y., Palmer, A. \& Petersone, E. The effects of passage of time on alumni recall of student experience. Higher Education Quarterly, 70(1), 59-80 (2016)

7. Hansen, L.L. Once students, forever alumni: A study analyzing drivers of alumni loyalty, Master Thesis, Carthage College (2015)

8. Pulley, J. The journey is the reward. Currents, 39(1), 16-21 (2013)

9. Berquam, L.M. Affinity development in undergraduate students at a large research institution, Doctoral Dissertation, Colorado State University (2013)

10. Stephenson, A.L. \& Bell, N. Motivation for alumni donations: A social identity perspective on the role of branding in higher education. International Journal of Nonprofit and Voluntary Sector Marketing, 19, 176-186 (2014)

11. Sun, X., Hoffman, S. \& Grady, M. A multivariate causal model of alumni giving: Implications for alumni fundraisers. International Journal of Educational Advancement, 7(4), 307-332 (2007)

12. Monks, J. Patterns of giving to one's alma mater among young graduates from selective institutions. Economics of Education Review, 22(2), 121-130 (2003)

13. Radcliffe, S. A Study of Alumni Engagement and Its Relationship to Giving Behaviors, Master Thesis, Bucknell University (2011)

14. McDearmon, J.T. \& Shirley, K. Characteristics and institutional factors related to young alumni donors and non-donors. International Journal of Educational Advancement, 9(2), 83-95 (2009).

15. Young, P.S. \& Fischer, N.M. Identifying undergraduate and post-college characteristics that may affect alumni giving. AIR 1996 Annual Forum (1996) 
16. Truitt, J. The relationship between student engagement and recent alumni donors at Carnegie baccalaureate colleges located in the South Eastern United States (2013)

17. Hoyt, J.E. Understanding alumni giving: Theory and predictors of donor status. Paper presented at the meeting of the Association of Institutional Research (2004)

18. Weerts, D.J. Toward an engagement model of institutional advancement at public colleges and universities. International Journal of Educational Advancement, 7(2), 79 -103 (2007)

19. Markoff, R.M. An analysis of the relationship of alumni giving and level of participation in voluntary organizations: A case study. Toledo, $\mathrm{OH}$ : University of Toledo (1978).

20. Ayers \& Associates. Alumni giving in the new millennium: A guide to securing support. Washington, DC (2002)
21. Brant, K.E. \& Regan, P.J. The spectrum of alumni involvement. CASE Currents, 28(2), 22-28 (2002)

22. George, D. \& Mallery, P. SPSS for Windows step by step: A simple guide and reference (4thed.). Boston: Allyn \& Bacon (2003)

23. Norasmah, H.O. \& Salmah, I. Kecenderungan terhadap pemilihan kerjaya keusahawanan mengikut persepsi peserta skim usahawan siswa. Jurnal Teknologi, 56, 47-63 (2011)

24. Sekaran, U. Research Methods for Business, a Skill Building Approach 4th edition. Wiley, New York (2003)

25. Conner, D.K. Factors that affect alumni giving at a southeastern comprehensive university. Doctoral Dissertation, Clemson University (2005)

26. Gaier, S.E. The impact of alumni satisfaction with their undergraduate academic experience on alumni giving and alumni participation, Doctoral dissertation, Purdue University (2003) 